University of Louisville

ThinkIR: The University of Louisville's Institutional Repository

Electronic Theses and Dissertations

1935

\title{
Construction and application of a vacuum tube potentiometer.
}

\author{
R. Palmer Benedict \\ University of Louisville
}

Follow this and additional works at: https://ir.library.louisville.edu/etd

Part of the Chemical Engineering Commons

\section{Recommended Citation}

Benedict, R. Palmer, "Construction and application of a vacuum tube potentiometer." (1935). Electronic Theses and Dissertations. Paper 1666.

https://doi.org/10.18297/etd/1666

This Master's Thesis is brought to you for free and open access by ThinkIR: The University of Louisville's Institutional Repository. It has been accepted for inclusion in Electronic Theses and Dissertations by an authorized administrator of ThinkIR: The University of Louisville's Institutional Repository. This title appears here courtesy of the author, who has retained all other copyrights. For more information, please contact thinkir@louisville.edu. 


$$
\text { UNIVERSI TY OF LOUI BVILLE }
$$

CONSTRUCTION AND APPLICATION OF it

A VACUUA TUBE POTENTIOIETER

\author{
A Theolo \\ Subaltted to the Paculty \\ of the Graduate Sohool \\ In Partial pulfilaent of the \\ Requirements for the Degree of
}

Master of Bolonoe in Chomlosi Englnoering

Department of Chemloal Englneering

By

R. Palmer Benedict 


\section{ACKNONLEDAENENT}

The nuthor

withes to exprese his deep approclation

of the kind aselstance and oncouragment

or

Dr. R. C. Emst 
TABLE or CONTENRE

21at of Illuetrations 2

Llst of Tablea 3

Liat of Curves 4

Introduction 5

H1:torieal 8

Thooretioal 18

Experimontal 25

I Conetruetion and Operation 26

II Application to Ao10-Babe Titratione 35

III Application to Lead Chromate Plgments 49

Conoluetone $\quad 55$

Blbllography $\quad 57$ 
LIST OE LLUSERATIONB 
LIST OP TABLEB

I Titration of an Aold with a Bave 39

II Titration of an Acid with a Base 41

III Titretion of an Aeld with a Base 43

IV Titration of an Aold with Base 45

$\checkmark$ Legd Chromate Color: 53

vI Lead Chromate Color: 53 
LTST OF CUTVES

I Titration of an Aold with a Base 46

II Titration of an Aold with a Base 46

III Titration of an Acld with Base 46

IV Titration of an Aold with Base 46 
$-5-$

IHTRODUCTION 
In a previous investigation of a racuum tube potentiometer designed for applioation to potentiowetric methods, the instrument construoted ${ }^{14}$ was found to laok sufficlont sonsitivity and diverelty of application.

The present Imeatigation was undertaken to redesign the instrument to overcome the diffloulties experienoed with the previou instrument. It 1s further planned to apply the instrument to Industrial operation.

The epplication of the instrument to potentiometrio titrations using the quinhydrone and Blass lectrodes, and to conductionetric titrations w111 be undertaken. An attempt $\mathbf{w 1 1}$ be made to apply the instrument with the glase eleotrode to dotermine the pH of lead and chromate solutions a related to the reaulting color of lead chromate plgments.

The apparatue is eseontially a roouum tube potentloneter so constructed that 1 t $\$ 111$ indicate the presenoe of a rery smell potentlal differenoe, and at the same time dra practioally no current. It 18 to be constructed from comercial radio parts that can be eally obtained. It 1 to be operated from 110 volts AC. 
$-7-$

The purpose of the Investigation is to demonstrate that through the application of vacuum tubes, an instrument of general electrochemlesl utility can be built at low cost that $\mathbf{w 1 1 1}$ replace expensive galvanometers of high resistance, and that will reduce the errors due to audible measurements. 
$-8$

HTSTOEICAL 
The appliostion of raouun tubes to the measurement of eleotrochodieal potentials is not new. The flret publiahed elroult was developed by ooode In 1922. Goode applied the raouum tube to the quinhydrone eloctrode. He placed the oell in the grid olroult of the tube and callbrated a calranomoter in the plate olroult of the tube to read the potential. Th1s olroult wa operated entirely from batterles. Great care was nocessary to make sure that all the potentlals on the tube wore the wate whener the inotrument wa used, in ordor that the callbration would be valld.

Calhane and Cushing in 1923 conetmoted an instrument almiliar to that of Goode, except that they applied a grid blas to the tube, whereas coode did not. The only advantage of thelr instrument over that of Goode 1. that the grid current of the tube os of a lower order. The same care in setting up the instrument is neoessary.

Partridgo conotrueted an 1notrument -iniliar to the direct coupled atea of clark: Th1. olroult was published in 1929. The Clark clroult wa flret published and patented about 1915. The differenoe between the olrcult of Partridge and the elroult of Clark 1s that Partridge 
used a totrode and a triode, whore liark used two triodes. Thls systen used battorles for a souroe of power and used a method of moasurement similiar to the method used in the instrunent constructed in thie Invest1gation. The Partridge elroult 1a unotable, showling a tendeney for the plate current of the lant tube to inorease with time of operation. Otherw18e, it represented the best that could be obtalnod with the tubes avallable at the time. Rosebury bullt an Instrument lolliar to that of coode exoept he used a commerolal tetrode instead of a triode. The olreult is no doubt acourete, but it is very complloated and requires more apparatue than the standard glase electrode potentlometer, and it is no nore sccurate. Goode" al wo bullt a dreot reading pH moter using three tubes known a iv199. Ho Inoluded an elaborate mothod for reatandardiation. The olreult was the same as that of clark. It wa a practical instrusont, but 1t is now out of date, beosuse the tubes have been replaced by superior tubes.

In 1930 Major Lortin and Captain White of the slgnal Corpe developed direct coupled amplifler. While thi. amplifler wa developed as 
$-12-$

an audio frequeney amplifier, it can be slightly modified and used a direct ourrent amplifier. In 1934 Benediot bullt an inotrument uelng a mirled Lortin-white ciroult. The instrument wh of aple construction and produced fals reaulte, but 1 t was not ent1rely satifactory an it was not rory sonative and floxible. 
$-12-$

THEORETTCAL 
W thin the last two years there have been developed racuum tubes that lend thenselves very we11 to the construetion of a vacuum tube voltweter of very high resistance and sensitivity. The necessity of a hleh resistanoe in a voltweter 1 apparent when one oonsiders the resistance of the eource of potential used in slectrochenteal moa eurements.

In order to mere olearly undergtand how a vecuum tube may be aade to preform the operetions of a galvanontere, it w11l be necessary to alsoums at length the theory of operation of a vacuum tube.

It 1. a well knom fact that when a body 1s heated to Incandescence it w111 enit electrons. This property is mod use of in vaouum tubes. The Illawent of the tube is heated and it onits electrons. Due to the property of these ilectrone, if a positively oharged plate is pleced in olose proximity to the rilament, the olectrons w111 be attracted to this plate. The result is a flow of electrons, and henoe a flow of current. But it this plate were made negative with reapeot to the rliament, no curment would flow, because the electrone would be re- 
pelled from the plate. If an altermating ourrent were 1 mpressed across the aysten, current would flow only during the half of the eyele in which the plate was positive. Thle is the action of the rect1rler tube that is used to convert alternating ourrent into direot ourrent. (The output of the rectifier muat be moothed by the use of adequate (11terg.)

If another plate that 1s porous to electrons 1. Introduced between the flrat plate and the rliament, 1t w111 rocelve 1ts share of electrone ondted by the Pllament. This second plate is actueily a co11 or looeely woven sereen of w1re placed between the fllament and the plate, and 1t is called a grid. If no charge is placed on the grid, it has no effect upon the action of the tube. But $1 f$ the grid is made positive with respect to the fllament, it will attract electrons. The grid however, is not solld, so only part of the lectrons w11l atrike 1t. The eleotrons that do not etrike the grid are acoelereted and eventually otrike the plate. Sinee all the eleotrons that were enitted by the fllament did not reach the plate when the grid was free, becaused they did not have enough relocity to get theres when the grid is made oositive, more current will flow in the plate olroult, because the electrone have been acoele- 
rated and now more of thes reach the plate. If on the other hand the erid had been made negative with respect to the rilament, then the eleotrono would have been repleod by the grid (none would otrike the grid if it were made cuffiolently negative), and fewer eleotrons would have reached the plate. Consequently when the grid If negative, less plate current w111 flow. If an alternating current is Impressed upon the grid, the plate ourrent of the tube w111 have the ane wave forw (1f the amplitude 1 s not too great) that the grid roltage hal, except that inatead of belng of the sero axis, It will be ent1rely on the positive side of the zero ourrent axis. The plate current of an ordinary veouu tube is never nogative. the foregolng diecusalin of the action of the fird has been quelitive 1te quantitive action, horever, depends upon the actual construetion of the tube. If the grid is widely speed and placed closer the the filament than to the plate, the ohange in plate ourrent w1ll be wuoh greater for a given ohange In Grid voltage than if the grid were oloser to the plate than to the fllawent. The ratlo of the change In grid roltage to a ohange in plate voltage that w111 produce the eame ohange in plate current,for a sall 
changer, 1s called the anplifleation factor of the tube, or 1t is sometimes called the wu of the tube. It would seem that the mu of a tube could be increased without 11ndt by making the grid with samlior openings and noving the plate farther away. It would be well to mention the fact thet a tube must not draw grid current, which it will do if the grid is positive, because when the grid draws ourrent, 1t will be useless for the purpose for which it is to be used a $\mathbf{1 1 1}$ be shown later. The wu of the tube cannot be increased without $11 \mathrm{ml} t$, because as soon as the plate 1s moved away from the fliament, the plate ourrent $\mathbf{w 1 1}$ decrease. Th1s is due to the fact that the lectrons w111 not be moring fast enough to reach the plate. S1noe the grid is larger and must be negative, the plate ourrent w11l ouffer a rurther decreane. Therefore, as the mu 1noreases, the plate ourrent 1111 decrese until it 1. Infinitedimal. This low plate ourrent bring in another factor--the plate reslatanee, which 18 the $p$ plate roltage divided by the plate current. It is a well known fact the the load on the cenerator muat be be equal in resiatance to the generator in order to have the most efflelent use of the power aupplied. If the plate current approachen zero, the plate 
reelatance will approach infinity, and coneequently the loed resistanee sust approsoh infinity. It has been demonstrated wathowatically that in ordor to utilize $50 \%$ of the wu of the tube, the load resietance must equal the plate reslotanee. Ih1s meane that very high roltege drope w111 oocur in the load. Astuming that the load realstanoe could be made equal to the plate resiatance, the ourrent would be so sall that the gain could not be uned. It might be argued that the plate voltage alght be rained to inorease the plate current by increaling the veloolty of the electrons. This glves rise to another diffioulty. The fllament gives off only so many eleotrons, those that do not resch the plate float around in the space betreen the fliament ant the plate and saturate $1 t$. Th1s caturation offect blooks any further electron. from roohing the plate and inoresing the plate ourrent.

By adding another element to the tube some of the bad effeots of removing the plate from close proxinity of the fliament oan be partially overoome. This fourth element is oalled the soreen grid, and 1t 1. a soreen surrounding the plate. The offeot of It 18 to apeed up the electrons that get past the flrat or control grid, wo that they reach the plate 
and cause an inorese in plate current. As this woreen gria 16 positively chargeă, it recelves mome of the electrons, but the inorease in the number of electrome reachine the plate is greator than the number absorbed by the screen grid. Thls tube st1ll bas a mether high plate realstance, but is 18 very much lower than that for a three element tube of the Bane mu. If there some way of Incrasalng the plate voltege without oausing wecondery emleston, the plate resistnnce of the tube could be further reduced. Thle oan be done quite $1 \mathrm{mply}$ by the introduction of a sleth elesent, whlch 18 snother grid between the screen grid and the nlate, called the oupressor grid. The erld la normally connected to the plament and serves to trap any secondarily omitted - leotrone, thus keeplng the space surrounding the plate free frow electrons with no velocity, whioh tend to block the plate from the electrons enitted by the fllament. This grla can be used fro other functions a vell, but they have no bearine on this discuesion and will be omited.

There is another thematioal relation between the grid voltage and the plate current. It 16 the mutual conducetance or an of the tube. The change in plate current divided by the change in grid 
voltage neoeseary to produee that ohange in plate ourrent multiplied by $1,000,000$ 1s the and and 1 ts unlts are mlorowhos. (A taho 18 a reolprecal ohm.) It oan also be shown that the of is equal to the mu divided by the plate realstance in negohna. In order to be of the elightest use in - leotrochomical moseurements, the instrument must not draw ourrent from the source of potentlal $1 t$ 10 moasuring, because the cells used in the moasurements have high internal resistanoe. If some current 1. drawn from then, the potential moasured by the Instrument would be the actual voltage of the cell ainus the drop in the Intermal rollatanoe of the ce11. In conducatnoe aoamrenents with a Wheat- tone bridge this consideration io not so important, but the higher the rosistance of the ind1cating device, the aharper the balanoe. It may be of some interest to note that the input resistance of a vacuum tube is in the order of $20^{20}$ ohms. Th1 bring about the point of hor to ut1lize the racuun tube for roltage measuremente. The cell whose voltage is to be meavured can be connected in the grid clrcult of the tube in serles with anall battery arranged with a with so that the battery could be conneoted elther thru the 0011 or directly to the grid. The potential change in the 
battery neossary to bring the plate eurrent to the same value as when the oell was in the olroult is the potential of the cell. Or a curve of plate ourrent va. grid roltage osuld be plotted and the voltage of the oell deternined from the ourre. The second nethod Is not very satlefactory, bacauge the curve would ohange evory tine any part of the olroult changed. Sinoe It ie almost 1mpossible to keep all the parts of $a$ vacuum tube olreult oongtint for any length of tiae, frequent recalibration of the instrument would be necessary. With the firot mothod, a ohenge in the parts of the clroult wolid here rery 11 ttle effect upon the system, because these cahnge would be wow and the time consumed in maklng readine 1. wo short as to make the effect of the chengine conditions n11. There 18 a arabeck to the ure of a single tube, however, it 1 that the change in plate current of the tube for a change in grid voltage of the order of the voltage used in eleotrochentcel measurements for the neceseary accurecy, is on entil in comparian with the totel plate ourrent that it would be defleult to obtain an ingtmuant thet woud show the ohange in plate ourrent. This is twue of olthar method. Fhen an sttempt to ues more than one tube 1. made there are coveral diffloulties that mut be overoome. It 1s rory imple to make an amplifier 
of one or more tuber that w11l amplify an alternating current as 1s tostified by the amplifier of a radio sot. But the problem 1s, in a mner of speaking, to amolify a direct current to such a point that 1t oan be measured. It is eany to woe that any system that depends upon transformers, or eapacities to transfer the voltage from one tube to the next w111 not work. The only moohani wa that w111 gatlafactorly tranufor a dreot ourrent roltage 18 a realetance. This means that the plate of one tube myat be direotly oonneoted to the grid of the next tube. This is not so diffloult as it seems. All that is neosasary is that the ohange in grid voltage of the first tube amplifled is applied to the grid of the second tube in ouch a manner thet for one erid voltage on the rirst tube, the second tube v111 have one plate ourrent; and that for sope other grid roltage on the of the flrst tube, the plate current of the second tube has ome other value. If the set up is such that the plate ourrent of the seoond tub is a function, not necesarily linear, of the grid voltage of the f1rat tube, and the rirst mohod of measurement is usod, the problew is oolvod. The foregolng condition can be rulrilied 
18 In the plate ciroult of the first tube there is a rentotor of sultable value so that noot of the mu of the firet tube is utilized, and the drop sorose this resistor applied to the erid of the second tube in series with voltage or such value as to leave only the proper grid blas on the cecond tube. From this it $\mathbf{w 1 1}$ be seen that the ohange in plate ourrent of the ceeond tube w111 be the product of change in erid voltage of the first tube, the om of the first tube, the load residance, and the $\mathrm{am}$ of the seoond tube. An the whole get-up w111 function 28 one tube withe the Gin that is the product of the an of the frist tube, the load resiatence and the Gr of the nocond tube. Thu tro tubes are made to function as one and the requirement for direct current amplieler 1s fureilled.

Ih1 eet up oan be apnlled to another nothod that is a variation of the firat mathod of belanciner. Instear of on battery in the erid clreutt there are two arranged with potentioneters so that the voltage can be varied. One of the roltages is made equal to the proper opereting blas, and the other is varind until its voltage is exaotly equal and opposite to the cell voltage. This point oan be determined by connocting the positive terminal 
of the blas battery to the rilaraent and arrangling the other termianl so that it can be connected to the grid directly or thru the bucking bettery and the cell to the exid. The bucking batter voltage Is ocual to the roltage of the cell when the plate current of the second tube show no change when the negative temalnal of the blasing hattery is connected in elther position.

When the set up is used for conductance mesarements the bucking battary is onitted, but the swltching arrangenent 1a retalned. it is conneoted so that the grid is oonnacted to the blasine battery elther thru the galvanoweter terminals of the wheatatone brigge or direct. The bridge is balanoed when there 18 no change in plate current of the second tube when the grid is changed from one oannection to the other. The potential oource of the bridge way be any thet le avaliable. If the bridge 18 one that has non-1nductive resistances, end prsctically no Internal capacit:, almost any frecuency within reacon my be used. If the bridge 1. not of the kighest nualty, it w11l probelby be necenen to use very low freouericy souree, becaue the couplIng thru the inductares and oepectty in the bridfe 
w11l not allow o harp bulane polnt to be obtalned. W1th a high quality bridge it is posatble to use a vacuum tube oscliator, and it 1 augsested that a c1roult with more inducatnoe than capaolty and with f battery blas be used to supnrese hamontcs. It 18 not Heoeseary to use audible erequencles with a good bridgo. If a loud opeakor $1 \mathrm{~s}$ connected in the plate clrcuit of the second tuhe thru the proper type onupling unit, an gudible ag well visible indicetion of the balance is obtolned. If a radio ereouency oscliator is used 1t will be necessary to shield all parts of the clrcult, as the amplifier by 1 t very nature Is a very sensttive recelvor and can plok up signals from the oscilator a well as it can from the bridge. A hlgh erequency 18 dealreble in conduotance measuromente in order to eliminate polarization. If aubdible belance ic desired at rado frecuencles, the bias battery of the ceollator may be replaced by a frtd lesk and condencer of such a velue ef to make it oelfmodulntine.

the amplifier nust be well shielded, becuare it 1s very censitive to sny sort of electrioal d1sturbance. 
EXPERIUENTAL

1 CONSFRUCTION AND OPRRATTON

II APPLTCATIOA TO ACID-BASE TITRATIONS

a QUINHYDRONE ITPATIONB

b QLASS ELFCTRODE TITRATIONS

- CONDUCTANCE TITRATIONB

III APPLICATION TO HEAD GHROMATE PIGMENTS 


$$
\ldots
$$


The ingtrument is shown dagramatioally

In Figure 1. The operation for visual belance is a. follows:

The cell potential is introduced across the Input terminals and applied to the grid of the 58 tube. In addition to the cell potential there 1. potent1la on the grid of the 58 tube for the purpose of keoping the grid negative at all times. chio potential 1s supplied by the bettery $B_{8}$ and the resistor $R_{0}$. The potentiel of the 0011 is opposed by means of the potential obtalned from the battery $B_{2}$ and the resistors $R_{2}$ and $R_{2}$. This opposing potential any be mosured by moans of a mil11voltweter or any other means that are desirable. If the opposing potential of the battery is the wase as the potentiel of the cell, there w111 be no ohange in the grid potential of the 58 tube when the ewitoh $s_{2}$ is moved from one position to the other. If the coll potential is not balaneed out, there w111 be a change in the grid potential of the 58 tube, and honce a change in 1ti plate ourrent. Inis change in plate ourrent will cause a change in the arop across the resistor $R_{0}$ which in turn will cause ohange in the grid potential of the $2 A 3$ tube and hence a change in the plate ourrent of the $2 A 3$ tube. 


\section{COMPONENTS OF ETOURE 1}

$R_{2} 100$ ohn potentloneter

R. 20 oh potentioneter

R., R. 200 ohm potentioneters

R. 2,000 ohn potentiomoter

R. 50,000 ohm potentioneter

$R_{0}, R_{7} 10,000$ ohm potent10setere

$R_{0}, R_{16}, R_{17} 500,000$ ohm fixed resintore

$R_{20} 5,000$ ohn elixed resistor

$R_{12}, R_{1}$. 25,000 ohn I1xed reelatore

$R_{10} 100,000$ fixed resistor

$R_{24}, R_{28} 50,000$ ohn elxed residotors

$R_{20} 40$ ohn rhoostat

$s_{2}$ BPDT puoh-button ow1toh

$3_{2}$ DPDT mitoh

$S_{0}, S_{4}, S_{6}, S_{6}, B_{1}, S_{0}, B_{20}, S_{22}$ SPST awitohes

S. BPDT aritoh

$\left.J_{1}\right) J_{0}, J_{0}, J_{1}, J_{0}, J_{0}, J_{\varphi}$ closed ofroult jacke

J. open olroult jaok

C 8 afd electrolyt10 condensers

120 henry ohokes

v $0-400$ millivoltmeter

$u_{2}$ O-L m1111anter

u. 0-15-150 mililammoter

$T_{1}, T_{8}$ Power traniformer: 700 volt $C T$.

2.5 volt ot., 5 rolt et., 5 rolt weoondaries 125 volt primarty 
The plate ourrent of the 58 tube 1t about 0.8 allilamperes and the value of the resiator $R_{0}$ is about 500,000 ohm, this mkes the drop about 400 volts. This drop leaves the erid of the $2 A 3$ tube about 300 volte aboue the gound potentlal, but the oathode of the $2 \mathrm{~A} 3$ tube 1a approximately 350 volta above the ground, whlch leares the proper operating bles of 50 rolt negative on the gxid of the 243 tube. The drop in the resiutor $R_{0}$ is adjusted so that the $2 A 3$ tube 1 arawing the proper plate ourrent, 50 millismperes, by varyling the earoen grid potential of the 58 tube by moans of the resistor R.. mon using the apparatus for visual ind1cation of balance, the owitoh 8 , 18 elosed and the awiteh s, 10 opened. This stabalize日 the operation of the apparatue by keepling the oathoded of the $2 A 3$ tube approximately 350 volts above the ground. In the plate elroult of the $2 A 3$ tube are the output terminal. $\mathrm{O}_{2}$ combined with the witoh $s_{\text {. }}$ to make provision for conneoting a loud-speaker or an adaltional millameter in the output olrcult. The awitch S. provides means of unltohing the devioe connected to the output $O_{2}$ in or out of the olroult. The realotor $R_{0}$ in conjunotion $\mathbf{w}$ th the bettery $B_{*}$ of the rectifler provides means of buoking the 
current thru the allilameter $H_{a}$ the output $O_{2}$ and the jaok Jo In such menner that the not ourrent thru all of then 1s approximately zero. Thls 1 s done so that the 0-1 millameter ay be plugged into the jack Jo to inerease the ceneltivity of the instrumont.

The resistore $R_{20}, R_{12}, R_{18}$ ? $R_{13}, R_{10}$, and $R_{\text {s, }}$ are multipliers for the milliamoter to make $1 t$ read the voltagen of the various parte of the circult. At the jaok $J_{2}$ is read the blas supplied by the battery $B_{a}$ and the realstor $R_{a} /$ at jack $J_{a}$, the blas supplied by the resistor Rat at Jaok $J_{0}$, the buoking blas supplied by the drop in the relsiators $R_{1}$ and $R_{1}$ I and jaok J., the roltage of the soreen Grid of the 58 tubes at jeok $J_{0}$, the potential of the cathode of the $2 A 3$ tubel at the jack J., the plate potential of the $2 A 3$ tube; at the jaok $J_{7}$, the plate potential of the $2 A 3$ tubes and athe the jack J. the alliamoter 1s used as an indloating woter to show a ohange in the plate current of the 243 tube for very acourate work.

When the devioe 18 used for audible meaturemente, the owitch $S_{\text {. }} 18$ olosed and the witoh $S_{8} 18$ opened. Then the oyetem is practically the sane as the Loftin-mite olroult, whioh has been fully discussed in the ilterature. 
The potentials for the plates and the Plamento of the vacuur tubes are obtained from the transformers $T_{2}$ and $T_{2}$. The alternating current is reotifled by the type 80 full-wave rectiflere and flitered by the chokes $L$ and the condensers $C$. For vieual indication of balance the aritohos $s_{1}, S_{3}, S_{1}$, and $s_{21}$ aro olosed and the witch 8. 1s opened. Then the AC current is turned on by the means of the enl the $s_{10}$. The cell is connected to the input terminals and alliroltmeter to 1 ts proper terainals. The resistors $R_{\text {, }}$ and $R_{6}$ are adjusted so that there 1. no drop aorosa then. The blas of the 58 tube 1s adjusted to -3 rolts by meane of the the realstro $R_{3}$, then the sereen grid voltage of the 58 tube is adjusted so that the plate ourrent of the $2 A 3$ tube 1650 milliamperes by means of the resiator $R_{6}$. Then the switoh $s_{0} 10$ closed and the roulatro $R_{0} 1$ ad austed so that the millaneter reads almost zoro. Then the plug is inserted in the jock $J_{0}$ and the realetor $R_{10}$ is plased in the position of ninimun resiotanes, then the switoh of 1 opened. The resistance of $R_{20}$ is increaced and at the same time the realotor $R_{0}$ is adfueted so that the 0-1 milliameter ataye on acale. Then the owitch $S_{1}$ (Th1 awiteh is of the pueb-button 
type, wired wo that in the normal position the grid of the 58 tube is connected to the blas battery.) 1. depressed and the resiators $R_{2}$ and $R_{2}\left(R_{1}\right.$ is for course and $R_{0}$ 1s for rine adjustmont) adusted so that the reading of the milliameter in the jaok J. 1. the same when the owitoh $g_{3}$ is releaged. The potential of the cell is then equal and opposite to the roltage read on the milivoltmeter. The owitoh s. w11l reveree the potential of the buaking battery. Whon the Inetrument is used for audible weacuremente the owltohos $\mathrm{B}_{0}, \mathrm{~S}_{1}, \mathrm{~S}_{0}$, and $\mathrm{S}_{12}$ are left open and $\mathrm{s}_{4}$ and $\mathrm{s}_{20}$ are olosed. Then the soreen $\mathrm{brid}$ potential 1s adjucted until it is the wase as berore. Then the resiators $R_{4}$ and $R_{p}$ are adjusted so that when the plate ourrent of the $2 A 3$ tube is 50 al11amperes, the potential measured at the jaok $J_{*} 1820$ volts and the potential at the jack J. 1s 3 volte lo 1est. The Instrument is now adjusted as LortinWhite amplifier, and way be used for any purpose that may be desired. It w111 180 function as detector or a wodulated ware.

Whan the instrument is used for a visual Indioator or conduotance measurements, it is adJusted in the same mannor as for potentiometric measurements. However, the balanoing is afferent. 
The switeh $s_{\text {s }}$ is opened and the Mheatetone bridge

1. adjusted so that there is no ohange in the

defleotion of the 0-1 milliampeter when the owitoh $s_{2}$

1s depreseded. This is the belanoe point. 
II APPLTOATION TO ACID-BASE TITRATIONS

a QUINHYDRONR ELECTRODE TLTRATION

D CLASS BLECTBODE TITRATIONB

2 conductance titrations 
The Intirument has been applied to eoldbase titration ueling the quinhydrone electrode, the glase electrode, and conductenee measurenents.

The polutions used in the aold-bese t1trations

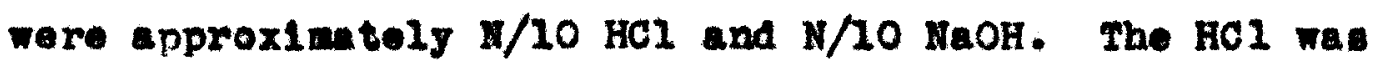
made up to approxinately $N / 20$ and etandardised $n 1$ th Na, $\mathrm{CO}_{\text {, und }}$ une quinhydrone electrode and the veouu tube potentionoter. The NaOH eolution was made up to approxiwately the wawe strength as the HCI and titrated roughly agalnst the HCl. The double break that was found Indleated that there was $\mathrm{Ha}_{8} \mathrm{CO}_{8}$ present, o the oaloulated amount of $\mathrm{Ba}(\mathrm{OH})$, was added to get rid of the cos. The solution was allowed to stand over night and was then f11tered. Another rough titration showed that the $\mathrm{CO}_{2}$ had been oonpletely remored.

The following titrations are given as typloal of thore obtalned with the methode used. A t1tration of the acid with the band uelng the quinhydrone lectrode and a sanderd potentioneter is giren in Table I

A titration of the acid and the base 16 Given in table II uelng the auinhydrone elom trode and the raouum tube potentioneter. In these titrations and the titrations with the glase eleetrode, a milivoltmeter was used to deteraine 
the potential of the buoking battery arter a balanes was obtalned. The nililvoltmoter was in the olrouit at all t1mes so that the ourrent drawn by 1 t would not cause an error in the readings.

In rable III is a typical titration obtained with the glase eloctrode and the racum tube potentiometer.

In the conduetance titrations, a Theatetone bridge and a morophone humer were used. The leotrode used was dipping eleotrode similiar to those used to find the conduetence of plating batha. A tjploal titration is given in rable IV. 
Table I Given the titration of $25 \mathrm{cc}$. of .1290N HCl with $.1302 \mathrm{~N}$ NaOH using the quinhydrone - leotrode and the standard potentioneter. 


\section{TABLE I}

TITRATION OF HCI WITH NaOH

$\begin{array}{lcl}00 . \mathrm{NaOH} & \mathrm{d} & \\ 0.0 & -0.388 \mathrm{dC} \\ 5.0 & -0.3830 & 0.0012 \\ 10.0 & -0.3785 & 0.0011 \\ 15.0 & -0.3625 & 0.0032 \\ 20.0 & -0.3445 & 0.0036 \\ 22.0 & -0.3290 & 0.0077 \\ 23.0 & -0.3160 & 0.0130 \\ 24.0 & -0.2890 & 0.0270 \\ 24.2 & -0.2780 & 0.0550 \\ 24.4 & -0.2600 & 0.0800 \\ 24.6 & -0.1900 & 0.3500 \\ 24.8 & +0.0460 & 1.2800 \\ 25.0 & +0.0990 & 0.2650 \\ 25.2 & +0.1320 & 0.1650 \\ 25.4 & +0.2600 & 0.1400 \\ 25.6 & +0.2860 & 0.2300 \\ 25.8 & +0.1970 & 0.0550 \\ 26.0 & +0.2090 & 0.6600 \\ 27.0 & +0.2240 & 0.0150 \\ 29.0 & +0.2270 & 0.0015 \\ 34.0 & +0.2295 & 0.0005\end{array}$


Table II gives the titration of $25 \mathrm{cc}$. of $.1290 \mathrm{~N}$ HC 1 with $.1303 \mathrm{~N}$ NaOH using the quinhydrone electrode and the racuun tube potentioner with allirol tmeter. 


\section{TABLE II}

TTPAaTON OF HeI with haOH

0. HaOH

NuP

$\mathrm{an} / \mathrm{ac}$

\begin{tabular}{|c|c|c|}
\hline 0.0 & -0.388 & $-\infty-\infty-\infty$ \\
\hline 5.0 & -0.384 & 0.0008 \\
\hline 10.0 & -0.378 & 0.0022 \\
\hline 15.0 & -0.364 & 0.0028 \\
\hline 20.0 & -0.342 & 0.0044 \\
\hline 22.0 & -0.332 & 0.0050 \\
\hline 23.0 & -0.312 & 0.0200 \\
\hline 24.0 & -0.282 & 0.0300 \\
\hline $24 \cdot 2$ & -0.276 & 0.0300 \\
\hline 24.4 & -0.256 & 0.2000 \\
\hline 24.6 & -0.192 & 0.3200 \\
\hline 24.8 & +0.044 & 1.2300 \\
\hline 25.0 & +0.098 & 0.2700 \\
\hline $25 \cdot 2$ & +0.130 & 0.2100 \\
\hline $25 \cdot 4$ & 0.285 & 0.2300 \\
\hline 25.6 & +0.284 & 0.1400 \\
\hline 25.9 & 40.194 & 0.0550 \\
\hline 26.0 & -0.208 & 0.0700 \\
\hline 27.0 & 40.222 & 0.014 \\
\hline 29.0 & +0.230 & 0.0040 \\
\hline 34.0 & +0.932 & 0.000 \\
\hline
\end{tabular}


Pable III gives the titration of $25 \mathrm{co.}$ or $.1290 \mathrm{H} H \mathrm{H}$ wth . $1302 \mathrm{~N}$ HOH using the glaes electrode and the rasuum tube potentioneter with a w111rolts neter. In this titration the 25 co. of acid was diIuted with 50 ce of $\mathrm{H}_{3} \mathrm{O}$ in orter to oover the glace eleotrode. 
TITRATION OF HCI WITH NaOH

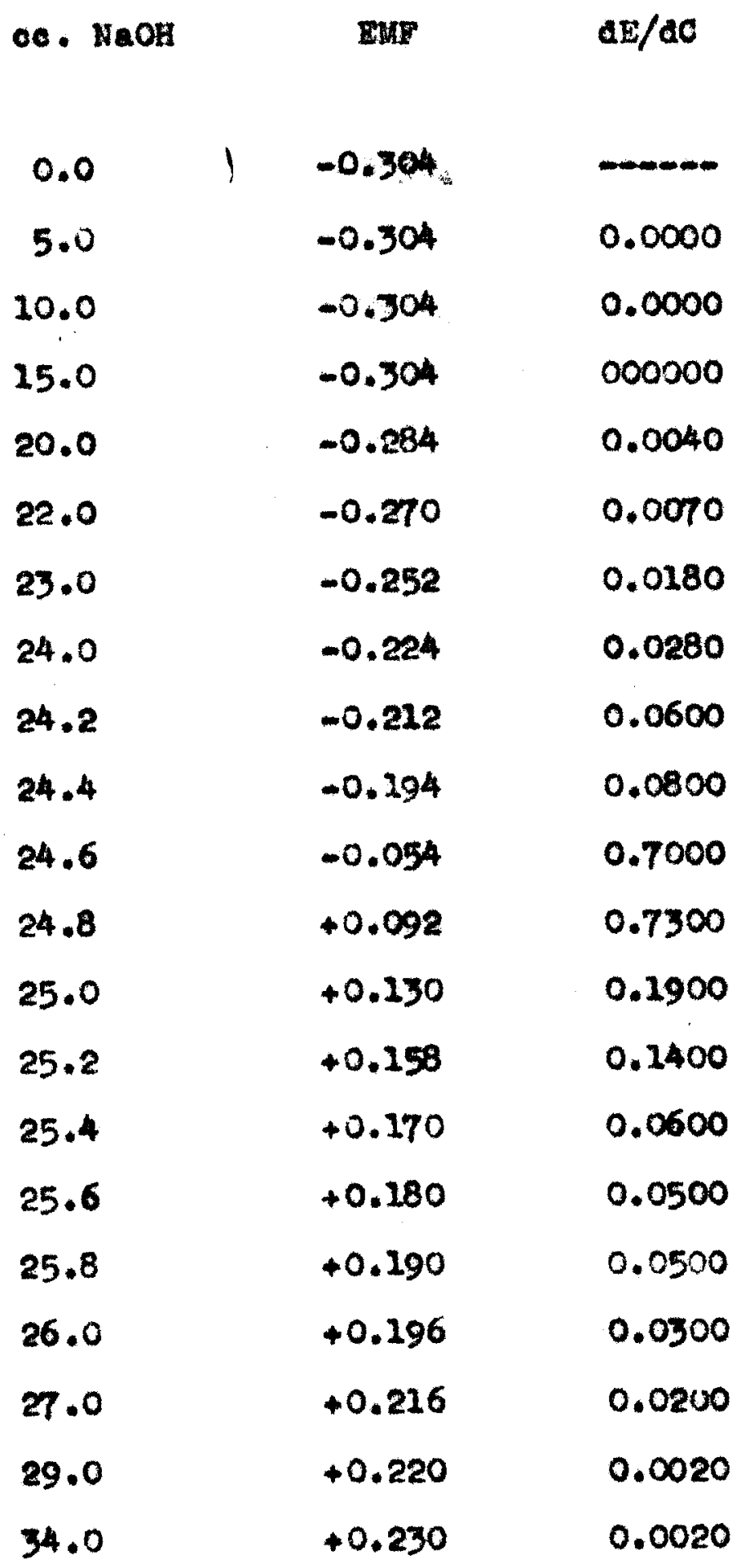


Table IV give the titration of 25 ce. of .1290 N HOL with . $1302 N$ NaOH by the conductanoe method, using the racuum tube set-up to Indicate the balanse polnt. In this titration the $25 \mathrm{co}$. of acid we alluted $\mathbf{m}$ th $50 \mathrm{ce}$. of $\mathrm{H}_{\mathrm{O}} \mathrm{O}$ in order to corer the alpping eleotrode. 


\section{TABLE IV}

TITRATION OF HOI WITH NaOH

\begin{tabular}{|c|c|}
\hline Co. $\mathrm{MaOH}$ & Revietance (Ohms) \\
\hline 0.0 & 12.9 \\
\hline 5.0 & 20.0 \\
\hline 10.0 & 24.0 \\
\hline 25.0 & 32.0 \\
\hline 20.0 & 45.0 \\
\hline 22.0 & 54.0 \\
\hline 23.0 & 59.0 \\
\hline 24.0 & 65.0 \\
\hline 24.2 & 65.8 \\
\hline 24.4 & 67.5 \\
\hline 24.6 & $68: 0$ \\
\hline 24.8 & 67.0 \\
\hline 25.0 & 66.7 \\
\hline 25.2 & 66.5 \\
\hline 25.4 & 65.8 \\
\hline 25.6 & 65.0 \\
\hline 25.8 & 64.5 \\
\hline 26.0 & 63.7 \\
\hline 27.0 & 60.4 \\
\hline 29.0 & 55.0 \\
\hline 34.0 & 40.0 \\
\hline 40.0 & 36.0 \\
\hline
\end{tabular}




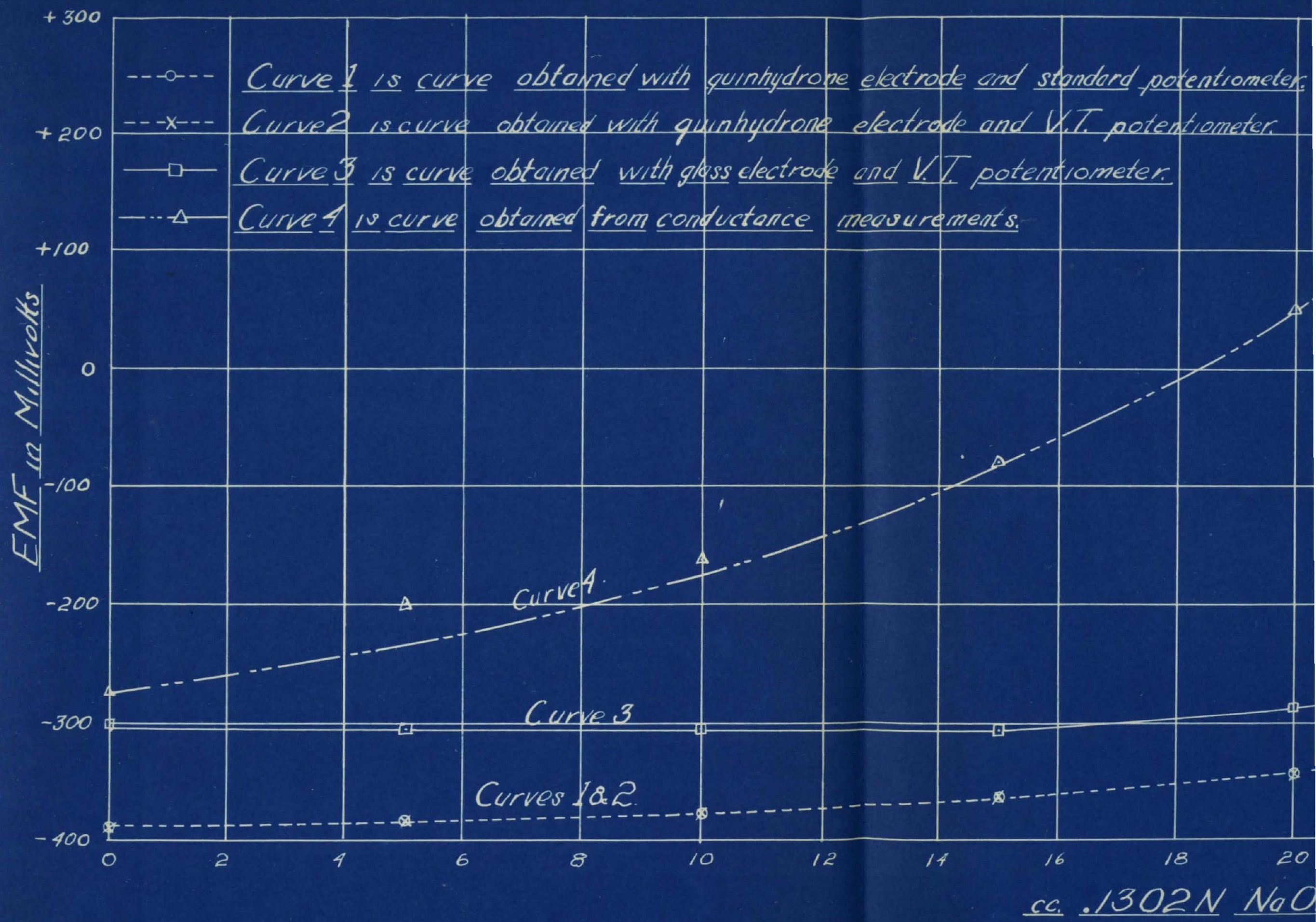


F plotting Evr againat co. the curvos 1 , 2, and 3 are obtained. The ond polnt of an ao1dbase t1tration 1s known to be at a pH of 710. This correspond to an of -0.044 . Therefore, where the eurve orosses the -0.044 ordinate 1 s the ondpoint of the titration, and the number of oo. 1. dotermined by exterpoleting to the abeiesa. In the three potentionetrle tliration the end-point found in the manner just decoribed was found to be 24.7200 . of MaOH.

By protting resistanos in ohme against oc. In conductionetrio titrations ourve 4 la obtained. The end solnt of the roaotion is at the peek of the curve. Ihts wa found to be 24.72 for the titration given in Table IV.

The greatest descrepeney between the racuum tube potentiometer and the atenderd potentioneter 1s only four millivolts. This 1. not so groat when it 1s conmldered that the mllilvol taoter cannot be read oloser than two millivolts. The curve of the glame electroce beging at a lower kMar(higherpH) than the other two ourves, because of the dilution with 5000 . Of $\mathrm{H}_{8} \mathrm{O}$.

Ueing the millivoltmeter the acouracy of the oysten is high onough for all praotieal purposen. Two millivolte corresponds to three hundredths of a pH. For greater acouraoy pot- 
entlomoter could be used in place of the millivoltmeter. The standard potent1ometer 1s callbrated to 0.05 millivolts, but the galvanoweter ordinarily used with it does not permit a balane closer than one millitolt.

The conductance surre is not so smooth as It salght be, but this is dus to the fact that the bridge used conteined small mount of Inductanoe and cepacity whloh prevented a sharp null polnt from beling obtsined.

These results show that almple vecuua tube potentloseter of moderate cost can replace the potentlometer and geivanometer row in uee, and oan be used as an id in conductance meseurements. rhis inetrument could bo portable for Induetrial application. It hould be cuffiolently acourate for most induatrial purposes. 


$$
-49=
$$

IT APRLTCATTON TO LFAD CHROULTE PTCHFNTS 
In this part of the applieation an attempt wa mede to apply the instrument with the glase electrode to the oontrol of the oolor of lead ohroinate plements. Spanyerse and others have shown that the oolor of the plgments to be a function of the pll of the etrikine colutions. In previoue Investigatians the quinhydrone electrode was uned to determine the pH of the oolutions. This presented the diffloulty that as coon as a ph greater than 7.0 was obtalned in the solution aftor striking, the quinhydrone would alscolor the plement.

In detorinine the $\mathrm{pH}$ of these solutione before striking, the glass aleotrode and the quinhydrone electrodes we placed in the solution at the sano t1me. It was found that the glasa electrode was stable and gave the ame reading for as long as Ifteon minuter, but the quinhjorone electrode gave - rosing of a pH bneller than the glass eleotrode and continued to drift towards lower ph the longer it in the solution. The same was true of the colutions after gtriking. 
The colutions of $\mathrm{Pb}\left(\mathrm{HO}_{4}\right)_{2}$ and $\mathrm{Na}_{2} \mathrm{Cr}_{4} \mathrm{O}_{4}$ wore made up to $0.5 \mathrm{I}$ and onough of each taken to prorlde $15 \mathrm{gm}$. of the dried plement. The $\mathrm{pH}$ of the colutions before striking we adjueted by the means of 5N HNO, and 5N NaOH ualine the glese olsotrode and the vacuue tibe potentlomator. In all cases the $\mathrm{Pb}\left(\mathrm{NO}_{6}\right)$, soluts on ras added to the $\mathrm{Na}_{2} \mathrm{Or}_{\mathrm{m}} \mathrm{O}$ eolution. The tro of atrikine wes approximetely 30 seconds. After atriking the pH of the solution wae determined with the glass - lectrode. Then the plement was washed three times by deoantetion and Plitered through a Bueohner funnel, and orled at $60^{\circ} \mathrm{C}$.

The $\mathrm{pH}$ of the lead colution wo found to be 5.2 and the chromete to be 2.5 in the $.5 \mathrm{~N}$ Bolutione.

reble $V$ howg the result of changing the pH of the chromate solution. Bamples 1, 2, 3, 4, 5. and 6 were all yoldow when atruck, but some hydrollzed to orange on the flrst wesh. Saraple 7 was orange when atruck. It was attempted to make the pH of eample 7 to be 11, but the highest pH that could be obtalned we 10.2.

Table VI howe the result of changing the pH of the lead solution. Bample 14 was the only one that was orange when struck. It may be interesting 
to note the the pH of axuple 14 if less tian that of ample 13, although anple 14 had 2.5 times as much base adied to 1 t as sample 13 . 


\section{TABLI V}

LEAD CHROMATE COLORB

\begin{tabular}{|c|c|c|c|c|}
\hline Bauple No. & $\mathrm{Na}_{\mathbf{a}} \mathrm{C}$ & & & \\
\hline & SWF & pH & EMPP & ph \\
\hline 1 & 20.160 & 5.0 & -0.398 & 1.0 \\
\hline 2 & -0.100 & 6.0 & -0.376 & 1.4 \\
\hline 3 & -0.040 & 7.0 & -0.070 & 6.5 \\
\hline 4 & +0.018 & 8.0 & -0.033 & $7 \cdot 15$ \\
\hline 5 & +0.077 & 0.0 & +0.035 & 8.25 \\
\hline 6. & +0.135 & 10.0 & +0.066 & 8.7 \\
\hline 7 & +0.142 & 10.2 & +0.142 & 10.2 \\
\hline
\end{tabular}

TABLE VI

ISEAD CHRUMATE COLORS

\begin{tabular}{|c|c|c|c|c|}
\hline \multirow[b]{2}{*}{ Sa mple } & \multicolumn{2}{|c|}{$\begin{array}{l}\text { IEAD CHR UIATE COLORS } \\
\mathrm{Pb}\left(\mathrm{NO}_{2}\right)_{2}\end{array}$} & \multicolumn{2}{|c|}{ Final } \\
\hline & Ex:P & $\mathrm{pH}$ & $\mathrm{E} M F$ & pH \\
\hline 8 & -0.160 & 5.0 & -0.123 & 5.7 \\
\hline 9 & -0.100 & 6.0 & -0.338 & 2.0 \\
\hline 10 & -0.040 & 7.0 & $-0.15 \epsilon$ & 5.1 \\
\hline 11 & $\$ 0.018$ & 8.0 & -0.140 & 5.4 \\
\hline 12 & +0.077 & 9.0 & -0.125 & 5.6 \\
\hline 13 & +0.135 & 10.0 & -0.094 & .05 \\
\hline 14 & +0.120 & 9.7 & +0.120 & 9.7 \\
\hline
\end{tabular}


Two moro anaple wore ade, 15 and 16 , in whloh the pH of both colutions was made up to ome definite value. In sample 15 both solutions were made up to $\mathrm{pH}$ of 7.0 and treated in the same manner a the prerlou saplos. The oolor after striking was orange, and the ph of the solution was 8.75 . In sample 16, both solutlon. were ade up to $\mathrm{pH}$ of 6.0 and treated in the anmo mner as the provlous eopples. The color on striking was yellow and the pH of the solution was 5.7.

An attempt was made to use the polarising microscope to obtaln ome olue as to the mechaniam of the color change of the plgnents as the oldity of the colution 1s decresed. The investigation with the microcope was of very little value, because the plgments seemed to be amorphus. It is possible the under a magnification of 5000 diameters that eame oryetal atructure my be in ovidenoe, but the hlghest power used, 1500 diametere, was not suffielent to resolve the oryetal, if there were any present. 
$-55$

conchustons 
The apparatus desoribed in this paper

was found to be atisfactory in every respect. It Ia seneltive and Flexible, and at the same t1me 1t 1s portable. The cont of the instmument built rrom atancar radio parti 18 about onerourth the cont of the atandard potentiometer for the glas olectrode. The instrument hac the further edvantage thet it contains no stendard cell to freeze or poletire, and no galvanometer with an eacily broken ouspention. It can be operated anywhere there is a 110 volt AC outlet. The results of the acia-bare titrations show thet the instrument is sufflelertly aocurate to be used for almeot any purpose.

The reault of the application the Instrument with the glase electrone to the determination of the pH of lead and chromate colutions In the striking of lead chromate plemente show that 1 t con be applied to operation Industrialiy. 


$$
-57=
$$

aLPI TGBAEHX 
BIPLIOGRAPHY

1. Goode, J. Amer. Chem. Soe., 26 (1922).

2. Calhane and Cuahing, J. Ind. Eng. Chen., 15, 1118 (1923).

3. Partridge, J. Amer. Chem. Soc., 51, 1, (1929).

4. Rosebury, J. Ind, Eng. Chem. (Anal.), 4, 398 (1932)

5. Goode, J. Amer, Chem. Soo., 47, 2483 (1925).

6. Fleming, IST, XIY, 37, Haroh 1930.

7. Lew18, J. Amer. Ohom. Soc., 32, 1459 (1910),

34, 119 (1912); 35, 340 (1913); 37, 1983 (1915):

Allman and Polack, J, Chem. Soo., 115, 1020 (2919).

Knoble, J. Amer. Chen Soo., 45, 232 (1923).

8. B11lman,J., J. Agri. So1., 14, 232 (1923).

9. Loftin and hite, Had1o Vews, $21,704,800$, 890, 1004, 1105. (19304., Proc. IRE harch 1923.

10. Flemning, Radio News, 11,115 (1930).

11. Wirelose Prinolples and Practice, L. S. Palmer, Longman and freen, London 1928.

12. Elements of Padio Communioation, J. H. Morecroft, John W1 ley end Sons, Ine, New York, 1929.

13. Txperimental phyeloal Chemistry, Danela, Uathers, and 1 llians, MoOran H1ll Book Company, Inc.. New York, 1929.

14. Potentionetrio Titration, Kohltoff and Furhean. John Wiley \& sons, Ino., New York (1926) 
15. Taylor, Treatiee on Phyaloal Chemietry, Vol II

D. Van Nowtrand Co. New York (2924).

16. Crolghton and BInk, Elootroohemistry, 2nd Ed., Vol I, John wiley and Sone, Ino., Now York. (1928).

17. Bonediot, R. P., A Vacuum Tube Potentiomoter for use with A alass Electrode., U. of. L. (1934)

18. Spanyer, Lead Chromate P1gments, U. of L. 1931

19. Morr14, Motall10 Chromates, U. of L. (1932) 